\title{
Seed Treatment with 2,4-Diacetylphloroglucinol-Producing Pseudomonads Improves Crop Health in Low-pH Soils by Altering Patterns of Nutrient Uptake
}

\author{
Rosa E. Raudales, Erica Stone, and Brian B. McSpadden Gardener
}

Department of Plant Pathology, The Ohio State University, Ohio Agricultural Research and Development Center, Wooster 44691. Accepted for publication 5 January 2009.

\begin{abstract}
Raudales, R. E., Stone, E., and McSpadden Gardener, B. B. 2009. Seed treatment with 2,4-diacetylphloroglucinol-producing pseudomonads improves crop health in low-pH soils by altering patterns of nutrient uptake. Phytopathology 99:506-511.

Seed treatment with a 2,4-diacetylphloroglucinol (DAPG)-producing Pseudomonas strain ameliorated abiotic stress disorder in corn caused by growth in a low-pH soil. In two consecutive growing seasons, Wood1Rtreated seed gave rise to plants that grew taller $(P \leq 0.05)$, had fewer foliar lesions $(P \leq 0.10)$, and provided greater yields $(P \leq 0.1)$ than the negative controls when grown in soil with a $\mathrm{pH}<5.0$. Under controlled conditions, seed treatment with Wood1R also reduced foliar lesion sever-

root growth in young seedlings grown in acidic soil. Significant $(P \leq$ 0.05 ) patterns of altered mineral nutrient uptake (i.e., generally increasing $\mathrm{P}$ and $\mathrm{Mg}$ while reducing $\mathrm{Al}$ ) were observed to occur as a result of Wood1R seed treatment under both sets of growing conditions. In contrast, suppression of seedling damping-off disease was not indicated in this low-pH soil, because no difference in crop stand was observed for any experiment. Additionally, Wood1R-mediated growth inhibition of seedling pathogens was reduced in vitro at $\mathrm{pH}<5.0$, indicating that secretion of antifungal metabolites may not occur in low-pH soils. This is the first report of an abiotic stress amelioration of acid soil stress-related symptoms by a DAPG-producing pseudomonad.
\end{abstract} ity ( $P \leq 0.05$ in two of three experiments) but failed to increase shoot or

Diverse plant-associated pseudomonads have been shown to promote crop health (25). Pseudomonas fluorescens bacteria that produce the antibiotic 2,4-diacetylphloroglucinol (DAPG) are well known for their capacity to suppress diverse soilborne diseases (43), especially take-all $(7,30)$. DAPG producers are marked by the presence of $p h l D$, an essential gene involved in the biosynthetic pathway of 2,4-DAPG (1), and the mechanistic importance of the DAPG production for biocontrol of seedling damping-off and root rots is well established $(16,39)$. These bacteria can be readily recovered from most agricultural soils (17), especially on cereals such as wheat (26) and corn (24). The strain Wood1R of phlD+ pseudomonads which belongs to the genotype D was identified as the dominant genotype in corn fields in the state of Ohio (24), a genotype that was previously identified as a superior rhizosphere colonist and biocontrol strain (30,31). Recently, Rotenberg et al. (33) demonstrated that the abundance of phlD+ pseudomonads generally was positively correlated with corn stands and yields, though the precise mechanisms by which such responses occur are not entirely clear. In addition, although widely dispersed, it is not clear how the activities of DAPG producers vary with soil conditions.

Natural or artificial acidification of soils can negatively impact crop growth and yield, because low soil $\mathrm{pH}$ can significantly alter the availability of several mineral elements $(22,38)$. For instance, increased soil acidity can lead to excessive uptake of aluminum, manganese, and iron while simultaneously reducing the availability of essential plant nutrient cations (calcium, magnesium, and potassium) and anions (phosphates and sulfate). Acid soil conditions generally lead to poor root development that subse-

Corresponding author: B. B. McSpadden Gardener; E-mail address: bbmg+@osu.edu

doi:10.1094/PHYTO-99-5-0506

(C) 2009 The American Phytopathological Society
Additional keywords: phlD+ Pseudomonas fluorescens. quently leads to nutrient and water deficiencies in the plant (22). In addition, imbalances of essential mineral nutrients supplies ultimately affect yields (38). Although good agricultural management involves regular liming of soils to mitigate acidification, millions of farmers still work land with excessively low soil $\mathrm{pH}$ (37).

Little is known about the effect of low soil pH on DAPG producers and their interaction with plants. Naseby et al. (29) performed an assay testing the effects of strain F113 and G22, which is a DAPG mutant of F113, under acid conditions ( $\mathrm{pH} 4.4$ ) on pea plants. In that study, no differences in plant growth were observed between treated and untreated plants, even though the inoculated strains still altered microbial community structure to a measurable degree. Furthermore, Rotenberg et al (33) noted that the abundance of native populations of DAPG producers was generally negatively correlated with soil $\mathrm{pH}$ but positively correlated with stands and yields under typical growing conditions. In this study, we report the unexpected finding that DAPG-producing pseudomonads have the ability to control abiotic nutrient stress disorder caused by low soil $\mathrm{pH}$ (i.e., $\mathrm{pH}<5.0$ ).

\section{MATERIALS AND METHODS}

Seed treatment. The strain Wood1R of $P$. fluorescens was isolated from soils of Wood County, $\mathrm{OH}$ and was characterized to belong to the genotype D of phlD+ pseudomonads (24). P. fluorescens strain Wood1R was streaked from a glycerol stock into a $1 / 3 \times$ King Media B (KMB) agar and allowed to grow for $48 \mathrm{~h}$ at room temperature. Then, the bacteria were scraped from the agar plate and were resuspended in $1 / 10 \times$ tryptic soy broth (TSB). The concentration of the bacteria in the suspension was quantified by measuring the optical density with an ELx800 Universal Microplate Reader (Biotek Instruments, Inc., Vermont). Then, a bacterial concentration of $\log _{6}$ cells per gram of seed was 
applied in $1 \%$ volume to mass ratio. An equivalent volume of 1/10 TSB was added to seed used as a negative control. Planting was done within $1 \mathrm{~h}$ after treating the seed.

Field bioassay. The corn hybrid SC1091 (Seed Consultants, Inc., Washington Courthouse, $\mathrm{OH}$ ) was planted at a rate of 69,000 seeds/ha during mid-May for two consecutive years. The field was located on a research farm sited at the Ohio Agricultural Research and Development Center (OARDC) in Wooster, OH. The treatments were planted in a blocked factorial design, with each treatment being planted across two naturally occurring regions, delineated zone I and zone II, with differing soil $\mathrm{pH}$ and mineral concentrations (Table 1). There were two replicates per treatment consisting of rows that were $76 \mathrm{~cm}$ apart and 12 meters long. In 2006, the two soil zones were assessed together because the phenomenon was not observed until mid-July. Stand counts were taken 29 days post-planting when the majority of plants had reached V3 $(n=32)$ in both zones together. Because the stress differential was not observed until mid-July, plant height and percentages of leaf area covered with lesions were assessed when plants in zone II and the surrounding field were between V6 to V8. Yields were assessed by mechanical harvesting on 1 November using the SPC 40 two-row research combine with the Harvest Master Plot Harvest Data System (ALMACO, Nevada, IA). In 2007, stand counts and height from both soil zones were taken 28 days post-planting when most of the plants had reached V3 $(n=40)$. In zone II, eight plants per treatment were collected 48 days post-planting to measure plant height, foliar lesions, and nutrient uptake. Subsequently, the corn ears were hand harvested from each treatment and each zone on 9 October and yields were calculated using the following formula: $\left(\mathrm{kg} \mathrm{ear}^{-1}\right)$ (stand $\mathrm{m}^{-2}$ ) $\left(10,000 \mathrm{~m}^{2} \mathrm{ha}^{-1}\right)$ (ton $\left.1,000 \mathrm{~kg}^{-1}\right)(0.86)$. The 0.86 factor is an estimation of the amount of moisture based on the number used in the year 2007 by the Ohio Corn Performance Test program (28). The percentages of leaf area covered with lesions were calculated based on the Horsfall-Barratt grading system (4).

Experiments conducted under controlled conditions. Four experiments were performed with soils collected from the field described above. The first experiment (GH06) was designed to determine if the nature of the crop stress observed in the field was based on soil quality differences. The experiment consisted of a randomized complete design in which untreated seed of the hybrid SC1091 were planted in soils of zone I and zone II $(n=8)$. The soils for this experiment were collected during the first week of August 2006 from untreated areas of the field. Each soil sample was a composite of three subsamples collected $50 \mathrm{~cm}$ apart and approximately $15 \mathrm{~cm}$ deep. The soils were air dried for 5 to 7 days and then placed into small plastic pots $(10 \mathrm{~cm}$ in diameter by $10 \mathrm{~cm}$ in height) for conducting the bioassay. For the second greenhouse assay (GH07a), the remaining soils from zone II from the August 2006 sampling were combined and aliquoted into similarly sized pots. For the third (GH07b) and fourth (GH07c) experiments, the soils from zone II were collected on 25 June and 25 October 2007, respectively, dried, and mixed with the same approach described above. Experiment GH07c was done in a growth chamber. The 2007 experiments were established to determine the effect of Wood1R on corn health when planted into zone II soil. The corn was planted into the potted soils described above. Four seeds were planted per pot. Three independent experiments were established in completely randomized designs with $n=5$, 4, and 20 replicates for GH07a, GH07b, and GH07c, respectively. Each experiment consisted of two experimental treatments (i.e., seed treated with or without $P$. fluorescens strain Wood1R). The plants were collected 28 days post-planting and were measured for height, foliar lesions, root weight, and fresh shoot weight. Measurements of all the plants in each pot were taken and then averaged.

Soil nutrient content and plant nutrient uptake quantification. Soil and tissue samples were analyzed for nutrient content by the Soil Testing and Research Laboratory (STAR lab) at the OARDC immediately after sampling. Each independent soil sample consisted of the entire content of soil from the whole pot or the entire volume of soil that adhered to the root during sampling time for the controlled-conditions and field experiments, respectively. The tissue sample consisted of a composite sample of all of the whole plants in a pot for the pot assays and the whole plant collected for the field experiments. The number of soil and plant samples consisted of $n=5,4$, and 20 for GH07a, GH07b, and GH07c, respectively, and $n=8$ for the field experiment. The soil and plant tissue samples were air dried at 25 to 35 and $60^{\circ} \mathrm{C}$, respectively, and subsequently ground and sieved through a $2-\mathrm{mm}$ brass mesh. The soil $\mathrm{pH}$ was estimated by preparing a 1:1 deionized water and soil slurry and, after $10 \mathrm{~min}$, the $\mathrm{pH}$ was measured with an electronic $\mathrm{pH}$ meter (42). The available phosphorus (P) was determined with the Bray and Kurtz P1 test (8). In addition, exchangeable $\mathrm{K}, \mathrm{Ca}$, and $\mathrm{Mg}$ and the total cation exchange capacity were quantified with the ammonium acetate extraction method (41). The extractable $\mathrm{P}, \mathrm{K}, \mathrm{Ca}, \mathrm{Mg}, \mathrm{S}, \mathrm{Al}, \mathrm{Cu}, \mathrm{Fe}$, $\mathrm{Mn}$, and $\mathrm{Zn}$ were calculated with the Mehlich 3 Extraction and Induced Coupled Plasma (ICP) Mineral Analysis after microwave digestion. The shoots were evaluated for major elements $(\mathrm{P}, \mathrm{K}$, $\mathrm{Ca}, \mathrm{Mg}, \mathrm{S}, \mathrm{Al}, \mathrm{Cu}, \mathrm{Fe}, \mathrm{Mn}$, and $\mathrm{Zn}$ ) with the ICP mineral analysis after microwave digestion $(13,15)$.

In vitro inhibition assay. Pathogen growth inhibition mediated by Wood1R was tested at different $\mathrm{pH}$ levels. Subcultures of Fusarium graminearum, Rhizoctonia solani, and Pythium graminicola were incubated in potato dextrose agar (PDA). Agar plugs of the cultures were transferred to PDA amended with $1 \mathrm{M} \mathrm{KCl}$ or $2 \mathrm{M} \mathrm{NaOH}$ in order to obtain a desired $\mathrm{pH}$ of 4.5-6.5 in intervals of $0.5 \mathrm{pH}$ units. Fresh cultures of Pseudomonas fluorescens strain Wood1R grown in $1 / 3 \mathrm{KMB}$ were scraped and then resuspended in $1 / 10 \mathrm{TSB}$. Then, $10-\mu \mathrm{l}$ aliquots containing approximately $\log _{8}$ cells $/ \mathrm{ml}$ were transferred onto the agar plate with the pathogen avoiding direct contact. The plates were scored for pathogen growth inhibition 6 days after preparation on an ordinal scale of 0 (mycelia overgrowing the bacteria), 1 (mycelial growth to near $<1$ $\mathrm{mm}$ from the edge of the bacteria), or 2 (a clear inhibition zone of $>1 \mathrm{~mm}$ between the bacteria and the pathogens). Each assay included three independent replicate assay plates per $\mathrm{pH}$ treatment and the entire experiment was conducted twice.

Statistical analyses. Because the homogeneity of variance assumption was violated in several instances, nonparametric analyses of variance and association were applied (36). All the statistical analyses were performed using Minitab software (release 14.20; Minitab Inc., State College, PA).

TABLE 1. Chemical properties of the field soils used in this study ${ }^{\mathrm{a}}$

\begin{tabular}{|c|c|c|c|c|c|c|c|c|c|}
\hline Soil & $\mathrm{pH}$ & $\mathrm{P}(\mathrm{ppm})^{\mathrm{b}}$ & $\mathrm{K}(\mathrm{ppm})^{\mathrm{c}}$ & $\mathrm{Ca}(\mathrm{ppm})^{\mathrm{c}}$ & $\mathrm{Mg}(\mathrm{ppm})^{\mathrm{c}}$ & CEC (Meq $100 \mathrm{~g}^{-1}$ ) & $\mathrm{Ca}(\%)^{\mathrm{d}}$ & $\operatorname{Mg}(\%)^{d}$ & $\mathrm{~K}(\%)^{\mathrm{d}}$ \\
\hline Zone I & 5.3 & 55.0 & 64.5 & 526.0 & 72.5 & 12.1 & 21.2 & 4.8 & 1.4 \\
\hline Zone II & $4.7 * * *$ & 50.0 & $71.0^{*}$ & $122.5 * * *$ & $18.0 * * *$ & $13.5^{* *}$ & $4.7 * * *$ & $1.1 * * *$ & 1.3 \\
\hline
\end{tabular}

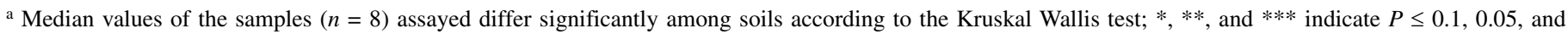
0.001 , respectively. Similar patterns of differences were observed in all subsequent samplings of the same two field locations.

${ }^{\mathrm{b}}$ Bray P-1 extraction method.

${ }^{\mathrm{c}}$ Exchangeable $\mathrm{Ca}, \mathrm{Mg}$, and $\mathrm{K}$, one-molar (1 M) ammonium acetate extraction method.

d Extractable Ca, Mg, and K, Mehlich 3 extraction. 


\section{RESULTS}

Crop health improvement under field conditions. The health of field-grown corn plants grown in a low-pH soil was markedly improved when the seed had been treated with the DAPGproducing Pseudomonas strain Wood1R (Table 2). This response was first noted in the 2006 field trial around the V7 stage. Although precise measurements were not taken at that time, field notes indicated that crop height and aboveground biomass in subplots grown from Wood1R-treated seed were approximately double that for adjoining sections of subplots where the seed had not been pretreated with the bacteria. Inversely, the percent leaf area affected by stress-related foliar discoloration was noticeably less in plots containing Wood1R-inoculated plants. In 2007, the effects of seed treatment on crop health were more precisely quantified, and similar positive responses to the seed treatment were observed (Table 2). At V4, corn plants treated with Wood1R were taller $(P<0.05)$ and the percentage of leaf area covered with lesions was less $(P<0.10)$. Additional plant measurements taken in 2007 (i.e., root weight and fresh shoot weight measured at V4) coincided with the differences noted in the plant height measurements. Median root and shoot fresh weights were greater $(P<0.05)$ for the plants treated with $P$. fluorescens strain Wood1R (data not shown). These two measurements were positively correlated (Spearman's $\rho \geq 0.665, P \leq 0.01$ ) with height, confirming that the plant height measurements were good proxies for plant health. Conversely, plant height and fresh shoot weight were both negatively correlated with the percentage of leaf area covered with lesions $(\rho \geq-0.503, P \leq 0.05)$. In contrast, no significant differences in crop stand were observed in zone II soils in either growing year $(P \geq 0.3)$.

Confirmation of the phenomenon under controlled conditions. Under controlled conditions, the plant stress caused by the zone II soils was noticeably lessened when seed were treated with P. fluorescens strain Wood1R (Table 3). Results of GH07a and GH07c experiments showed a significant reduction in the percent leaf area covered with lesions on plants arising Wood1Rtreated seed $(P<0.05$ and 0.001 , respectively). In these experiments, no significant differences in height $(P \geq 0.14)$ or root weight $(P \geq 0.25)$ were observed in any of the three experiments, indicating that plant growth promotion effects were not typically occurring during early growth stages when the plant were grown on acidic soil. As in the two field studies, no differences in stand counts were observed in these three studies $(P \geq 0.50$ for each), indicating that damping-off was not sig-

TABLE 2. Changes in median plant height, foliar lesion severity, and yields of field-grown corn resulting from seed treatment with Pseudomonas fluorescens strain Wood1R when grown in a low-pH soil ${ }^{\mathrm{a}}$

\begin{tabular}{lccc}
\hline Treatment & $\begin{array}{c}\text { Height } \\
(\mathrm{cm})^{\mathrm{b}}\end{array}$ & $\begin{array}{c}\text { Leaf area with } \\
\text { lesions }(\%)^{\mathrm{b}}\end{array}$ & $\begin{array}{c}\text { Yields } \\
\left(\text { ton ha }^{-1}\right)^{\mathrm{c}}\end{array}$ \\
\hline $\begin{array}{l}\text { 2006 } \\
\text { Wood1R }\end{array}$ & $>1.5 \mathrm{x}$ & $\mathrm{y}$ & $10.5^{*}$ \\
$\quad$ Negative control & $\mathrm{x}$ & $>2 \mathrm{y}$ & 8.1 \\
2007 & & $1.5^{*}$ & 12.2 \\
Wood1R & $53.8^{* *}$ & 28.0 & 11.2 \\
Negative control & 38.7 &
\end{tabular}

a Median values of the treated samples assayed within the same year differ significantly from the negative control according to the Kruskal Wallis test; $*$, **, and *** indicate $P \leq 0.10,0.05$, and 0.001 , respectively. Sample sizes were for $n=4$ (2006) and $n=8$ (2007).

${ }^{\mathrm{b}}$ Height $(\mathrm{x})$ and leaf area covered with lesions (y) for 2006 were measured when plants were at V6 growth stage and, although precise values were not obtained at the time, field notes confirm that all plants in the treated plot met the differentials noted. In 2007, data represents plants collected from the field at V4 growth stage. The leaf area covered with lesions was assessed using the Horsfall and Barratt rating system.

${ }^{c}$ In 2006, plots traversing zone I and zone II were mechanically harvested. In 2007, only zone II sections were harvested be hand. nificantly affected by the Wood $1 \mathrm{R}$ seed treatment under acidic soil conditions.

Relating crop health improvement to soil nutrient content and plant uptake. Significant correlations $(P \leq 0.05$ for all $)$ between plant height and foliar $\mathrm{P}, \mathrm{Ca}, \mathrm{Mg}, \mathrm{S}$, and $\mathrm{Cu}$ (positive for each) as well as B and Mn (negative for each) were observed (Fig. 1). On the other hand, the percentage of leaf area covered with lesions was positively correlated to Mn only and negatively correlated with $\mathrm{P}, \mathrm{Ca}, \mathrm{Mg}$, and $\mathrm{Cu}(P \leq 0.05$ for all). These statistical associations are consistent with the diagnosis that corn grown on zone II acid soils were suffering from an abiotic stress disorder.

Nutrient uptake in corn plants grown in the low-pH soil obtained from zone II was altered when $P$. fluorescens strain Wood1R was applied to seed prior to planting (Table 4). Most strikingly, plants treated with $P$. fluorescens strain Wood1R were better able to accumulate foliar $\mathrm{P}$ in all four experiments, though the noted increases were significant only in field07 and GH07c ( $P<0.10$ for both). Although not as striking, foliar levels of $\mathrm{K}$, $\mathrm{Mg}$, and $\mathrm{S}$ were generally higher and $\mathrm{Al}$ levels were generally lower in Wood1R-treated plants (i.e., in three of four experiments for each). These data indicate that the Wood1R seed treatment led to a significant amelioration of the abiotic stress disorder developing in response to the excessively acidic soil conditions.

In vitro inhibition assay. Because seedling damping-off was not suppressed by Wood1R in zone II soil conditions, we hypothesized that low $\mathrm{pH}$ decreased the expression of antifungal activities of the strain. To test this, pathogen growth inhibition bioassays were performed in vitro at varying $\mathrm{pH}$ levels. No inhibition of Pythium graminicola and $R$. solani by Pseudomonas fluorescens strain Wood1R occurred on PDA with $\mathrm{pH}<5$.0. However, Wood1R was able to consistently inhibit pathogen growth a $\mathrm{pH} \geq 5.0(P<0.05)$. In contrast, inhibition of $F$. graminearum by Wood1R was consistently observed across all of the acidity levels tested $(P<0.05)$. These data indicate that soil acidity may negatively impact some of the biocontrol capacities of DAPGproducing strains such as Wood1R, further counter-indicating the role of direct pathogen inhibition in the observed growth promotion response seen in the low-pH soil of zone II.

\section{DISCUSSION}

In this study, we provide the first evidence that DAPG producers can also act to ameliorate abiotic stresses associated with excessively low soil $\mathrm{pH}$. Specifically, foliar lesions induced on corn by growth on a low-pH soil were reduced significantly on plants that were seed-treated with the phlD + P. fluorescens strain Wood 1R (Tables 2 and 3). The observed lesions appeared to

TABLE 3. Pseudomonas fluorescens Wood1R-mediated reduction in the percentage of foliar lesions on corn plants grown in a low $\mathrm{pH}$ soil under controlled conditions ${ }^{\mathrm{a}}$

\begin{tabular}{lc}
\hline Seed treatment & Leaf area with lesions $(\%)^{\mathrm{b}}$ \\
\hline GH07a & \\
P. fluorescens strain Wood1R & $34.0^{* *}$ \\
Negative control & 53.5 \\
GH07b & 16.8 \\
P. fluorescens strain Wood1R & 7.1 \\
Negative control & \\
GH07c & $3.0^{* * *}$ \\
P. fluorescens strain Wood1R & 13.8 \\
Negative control & \\
\hline
\end{tabular}

a Median values of the treated samples rated 28 days post planting differed significantly from the negative control according to the Kruskal Wallis test; $*, * *$, and $* * *$ indicate $P \leq 0.1,0.05$, and 0.001 , respectively. GH07a, $n=5$; $\mathrm{GH} 07 \mathrm{~b}, n=4$; and GH07c, $n=20$.

b Percentage of leaf area covered with lesions was calculated with the Horsfall-Barratt disease rating system and includes white and purple necrotic lesions measured 28 days post-planting. 
result from abiotic nutrient stress because they occurred only on plants grown in zone II soils. Furthermore, the lesions themselves appeared similar to those generated by various abiotic nutrient imbalances, including $\mathrm{P}$ deficiency and Al toxicity $(38,44)$. One could anticipate that $\mathrm{pH}$ could have a significant impact on rhizosphere microorganisms' physiological and metabolic characteristics $(10,11,35)$. However, the fact that such microbial responses could lead to such a striking improvement in crop health under conditions of acid soil stress was surprising to us. The generality of the noted stress amelioration phenotype among the different strains of DAPG producers is not clear. It is well established that a high degree of genetic and phenotypic diversity occurs among DAPG producers (26), and such variability can affect their ability to compete in the rhizosphere of wheat (20) and other crop plants (6). Here, we used only Wood1R, a strain representing the dominant phlD genotype found on corn grown in Ohio (24) and previously reported to be a superior root colonizer $(30,31)$. It will be interesting to see whether other DAPG producers have similar capacities to reduce plant stress caused by low soil $\mathrm{pH}$ and whether such a phenotype is correlated with rhizosphere abundance of such bacteria on different crops.

Some other rhizobacteria have been shown to improve plant health by altering nutrient uptake or nutrient availability. It has long been known that Rhizobium and Bradyrhizobium spp. largely determine nitrogen content in legumes through the process of symbiotic nitrogen fixation (21). In addition, some Pseudomonas strains can increase mineral nutrient uptake based on their capa- city to solubilize phosphorus (5) or desulfurize sulfonate (18). Some other rhizobacteria can indirectly mediate nutrient uptake and, consequently, improve plant health through interactions with mycorrhizae (9). Still other bacterial inoculants have been shown to reduce stress caused by heavy metal uptake (3). Generally, one can conclude that beneficial effects of rhizobacteria are greatest under conditions of limitation or stress to the plant. This seems to be true whether the stress is abiotic (e.g., imposed by a soil with $\mathrm{pH}<5.0$ ) or biotic (e.g., imposed by the root pathogen complex). Here, the exact mechanisms by which Wood1R ameliorates the physiological stress imposed on corn by growth in low-pH soil remain unclear. Further work should reveal the generality of the observed phenomenon and its relative importance compared with the disease-suppressing activities expressed by Wood $1 \mathrm{R}$ and related strains in different soils with varying chemical properties.

A change in root growth rate or morphology may partially explain the Wood1R-induced stress amelioration. It is well known that a plant's capacity to obtain water and mineral nutrients from the soil is associated with its ability to extend its root system (34). However, under dry or nutrient-limiting conditions, root growth rates can slow down. Moreover, a change in root architecture has been identified as an important avoidance strategy by which plants adapt to abiotic stresses (22). Whether such activities occur in situ in field-grown crops such as corn remains to be investigated. Studies have shown that phosphorus uptake in corn and several other crop species is highly influenced by the density of root and root hairs (14,27). Recently, Brazelton et al. (2) demon-

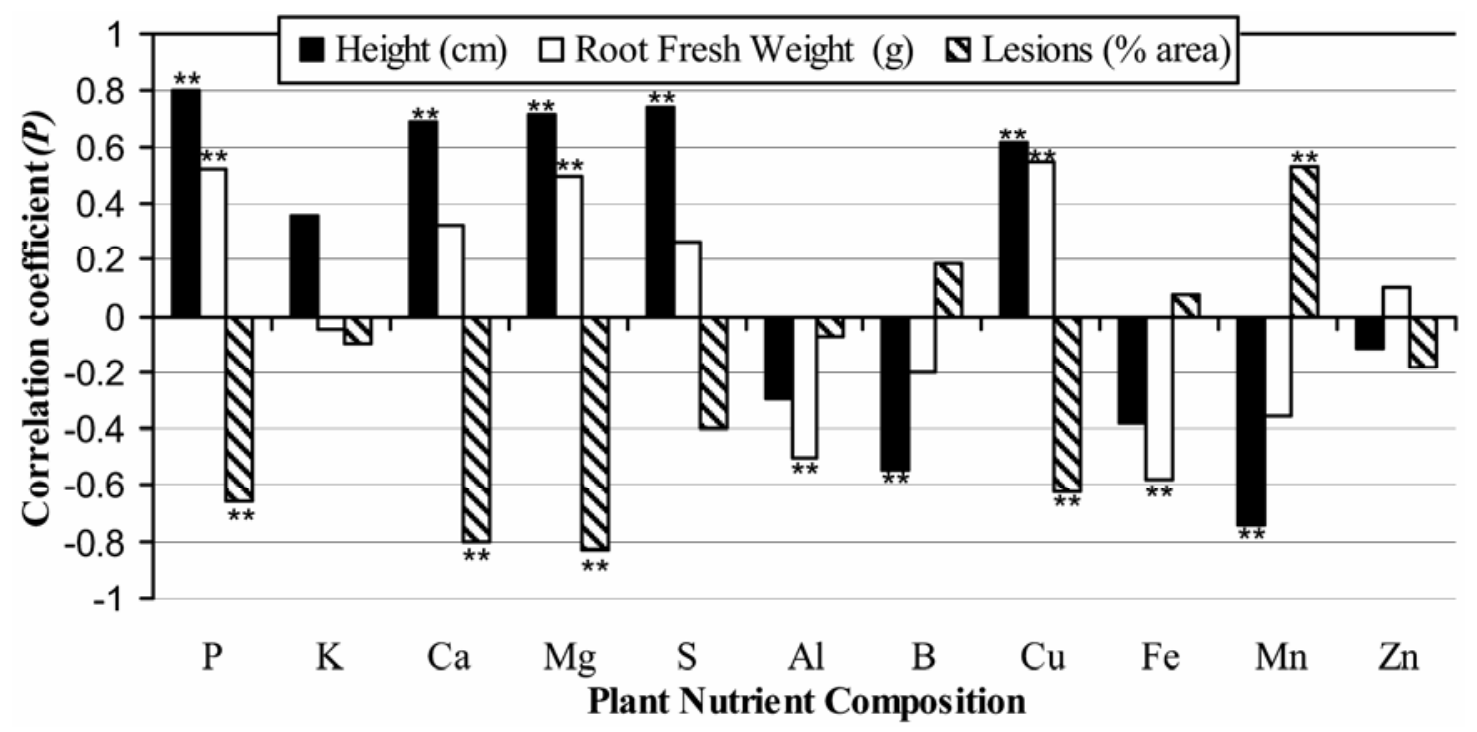

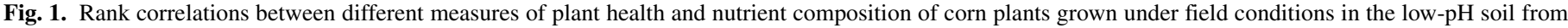
zone II. Significant Spearman's coefficients are noted; * **, and *** indicate $P \leq 0.1,0.05$, and 0.001 , respectively $(n=8)$.

TABLE 4. Changes in foliar nutrient composition of corn developing from seed treated with Pseudomonas fluorescens strain Wood1R when grown in low-pH soil

\begin{tabular}{|c|c|c|c|c|c|c|c|c|c|c|c|c|}
\hline \multirow[b]{2}{*}{ Experiment $^{\mathrm{a}}$} & \multirow[b]{2}{*}{ Treatment $^{\mathrm{b}}$} & \multicolumn{11}{|c|}{ Extractable minerals $(\mathrm{ppm})^{\mathrm{c}}$} \\
\hline & & $\mathrm{P}$ & $\mathrm{K}$ & $\mathrm{Ca}$ & $M g$ & S & $\mathrm{Al}$ & B & $\mathrm{Cu}$ & $\mathrm{Fe}$ & $\mathrm{Mn}$ & $\mathrm{Zn}$ \\
\hline \multirow[t]{2}{*}{ Field 07} & + & $3,167 *$ & 20,737 & $3,896^{*}$ & $1,796^{*}$ & 1,569 & 513 & $9 *$ & ND & 630 & 1,577 & 71 \\
\hline & - & 1,649 & 23,032 & 3,145 & 1,402 & 1,313 & 654 & 11 & ND & 598 & 1,874 & 73 \\
\hline GH07a & - & 1,654 & 19,379 & 4,822 & 1,860 & 2,242 & 81 & 15 & ND & 98 & 6,084 & 47 \\
\hline \multirow[t]{2}{*}{ GH07b } & + & 2,281 & 39,372 & 3,488 & 1,279 & 2,578 & 221 & 10 & 7 & 273 & 4,005 & 58 \\
\hline & - & 2,205 & 37,288 & 3,591 & 1,358 & 2,664 & 165 & 9 & 5 & 221 & 3,459 & 53 \\
\hline
\end{tabular}

a All corn (hybrid SC1091) was grown in low-pH soils obtained from zone II.

${ }^{\mathrm{b}}$ Presence $(+)$ or absence $(-)$ of Wood1R seed treatment.

${ }^{\mathrm{c}}$ Median values of the treated samples assayed within the experiment differ significantly from the negative control according to the Kruskal Wallis test; *, **, and *** indicate $P \leq 0.1,0.05$, and 0.001 , respectively; ND = not detected. 
strated that application of DAPG-producing pseudomonads or exogenously applied DAPG itself could increase root hair density and secondary root growth in tomato seedlings. Preliminary in vitro assays conducted in soil extract agar media showed that root length of seed treated with $P$. fluorescens strain Wood1R was similarly decreased; however, detailed evaluation of secondary root growth and root hair formation was not conducted (data not shown). Nonetheless, our field data showed that the root fresh weight of plants treated with Wood1R was positively correlated with $\mathrm{P}, \mathrm{Mg}$, and $\mathrm{Cu}$ and negatively correlated with $\mathrm{Al}$ and $\mathrm{Fe}$ (Fig. 1), suggesting that root development might have been improved by the enhanced uptake of such nutrients (Table 4).

Because the relative abundance of DAPG producers has been correlated with improved stands and yields of corn grown under various field conditions (33), we hypothesized that multiple mechanisms expressed by such strains can contribute to improved crop health. It is well established that DAPG producers can mediate specific pathogen suppression and provide for biological control of several different root diseases (43). Although antibiosis of root pathogens is one established mechanism of action $(17,39)$, DAPG producers, and DAPG itself, can also induce plant host defenses pathways and alter crop root morphology under certain conditions $(2,12,23,40)$. Such different host responses indicate that a single strain (or population) of DAPG-producing rhizobacteria can act in multiple ways to promote crop health (32). This idea is not new, because biocontrol and plant-growth promotion attributed to various rhizobacteria have been previously referred to as "two sides of the same coin" (19). However, it now seems clear that the full spectrum of rhizobacterial activities that lead to improvements in crop health must certainly extend beyond the commonly measured responses of disease suppression and early-season growth promotion. It will be essential to identify and characterize the expression of these different mechanisms if we are to fully explain the yield enhancements generated through seed inoculation with DAPG-producing pseudomonads and other biocontrol microbes.

\section{ACKNOWLEDGMENTS}

We thank D. Sanchez, B. Bardall, and the Snyder Farm field crew for their assistance in planting and harvesting of the field plots; and R. E. Raudales thanks M.-S. Benitez for her support throughout the project.

\section{LITERATURE CITED}

1. Bangera, M. G., and Thomashow, L. S. 1999. Identification and characterization of a gene cluster for synthesis of the polyketide antibiotic 2, 4-diacetylphloroglucinol from Pseudomonas fluorescens Q2-87. J. Bacteriol. 181:3155-3163.

2. Brazelton, J. N., McSpadden Gardener, B. B., and Coenen. 2008. 2,4Diacetylphloroglucinol alters plant root development. Mol. Plant-Microbe Interact. 21:1349-1358.

3. Burd, G. I., Dixon, G., and Glick, B. R. 1998. A plant growth-promoting bacterium that decreases nickel toxicity in seedlings. Appl. Environ. Microbiol. 64:3663-3668.

4. Campbell, C. L., and Madden, L. V. 1990. Introduction to Plant Disease Epidemiology. John Wiley \& Sons.

5. Datnoff, L. E., Elmer, W. H., and Huber, D. M., eds. 2007. Mineral Nutrition and Plant Disease. American Phytopathological Society, St. Paul, MN.

6. De La Fuente, L., Landa, B. B., and Weller, D. M. 2006. Host crop affects rhizosphere colonization and competitiveness of 2,4-diacetylphloroglucinol-producing Pseudomonas fluorescens. Phytopathology 96:751762 .

7. de Souza J. T., Weller, D. M., and Raaijmakers, J. M. 2003. Frequency, diversity, and activity of 2,4-diacetylphloroglucinol-producing fluorescent Pseudomonas spp. in Dutch take-all decline soils. Phytopathology 93:5463.

8. Frank, K., Beegle, D., and Denning, J. 1998. Phosphorus. Pages 21-23 in: Recommended Chemical Soil Test Procedures for the North Central Region. NCR Publ. No. 221. Missouri Agricultural Experiment Station, Columbia.
9. Garbaye, J. 1994. Helper bacteria: A new dimension to mycorrhizal symbiosis. New Phytopathol. 128:197-210.

10. Glenn, A. R., and Dilworth, M. J. 1991. Soil acidity and the microbial population: Survival and growth of bacteria in low pH. Pages 567-579 in: Proc. Second Int. Symp. Plant Soil Interact. Low pH. Beckeleey, WV.

11. Hoitink, H., and Boehm, M. 1999. Biocontrol within the context of soil microbial communities: A substrate-dependant phenomenon. Annu. Rev. Phytopathol. 37:427-446.

12. Iavicoli, A., Boutet, E., Buchala, A., and Métraux, J. P. 2003. Induced systemic resistance in Arabidopsis thaliana in response to root inoculation with Pseudomonas fluorescens $\mathrm{CHA} 0$. Mol. Plant-Microbe Interact. $16: 851-858$.

13. Isaac, R. A., and Johnson, W. A. 1985. Elemental analysis of plant tissue by plasma emission spectroscopy: Collaborative study. J. Assoc. Off. Anal. Chem. 68:499-505.

14. Itoh, S., and Barber, S. A. 1983. Phosphorus uptake by six plant species as related to root hairs. Agronomy 75:457-461.

15. Jones, J. B., Sr., Wolf, B., and Mills, H. A. 1991. Microwave digestion using CEM microwave digestion system. In: Plant Analysis Handbook. Micro-Macro Publishing. Athens, GA.

16. Keel, C., Schnider, U., Maurhofer, M., Voisard, C. Laville, J. Burger, U., Wirthner, P., Hass, D., and Defago, G. 1992. Suppression of root diseases by Pseudomonas fluorescens CHA0: Importance of the bacterial secondary metabolite 2,4-diacetylphloroglucinol. Mol. Plant-Microbe Interact. 5:4-13.

17. Keel, C., Weller, D. M., Natsch, A., Défago, G., Cook, R. J., and Thomashow, L. S. 1996. Conservation of the 2, 4-diacetylphloroglucinol biosynthesis locus among fluorescent Pseudomonas strains from diverse geographic locations. Appl. Environ. Microbiol. 62:552-556.

18. Kertesz, M. A. Fellows, E., and Chmalenberger, A. 2007. Rhizobacteria and plants sulfur supply. Adv. Plant Microbiol. 62:235-268.

19. Kloepper, J. 1993. Plant growth promoting rhizobacteria as biological control agents. Pages 255-274 in: Soil Microbial Ecology Applications in Agricultural and Environmental Management. M. Dekker, New York.

20. Landa, B. B., Mavrodi, D. M., Thomashow, L. S., and Weller, D. M. 2003. Interactions between strains of 2,4-diacetylphloroglucinol-producing Pseudomonas fluorescens in the rhizosphere of wheat. Phytopathology 93:982-994.

21. Long, S. R. 1989. Rhizobium- legume nodulation: Life together in the underground. Cell 56:203-214.

22. Marschner, H. 1991. Mechanisms of adaptation of plants to acid soils Pages 683-702 in: Proc. Second Int. Symp. Plant Soil Interact. Low pH. Beckeleey, WV.

23. Maurhofer, M., Hase, C., Meuwly, P., Métraux, J.-P., and Défago, G. 1994. Induction of systemic resistance of tobacco to Tobacco necrosis virus by the root-colonizing Pseudomonas fluorescens strain CHA0I: Influence of gacA gene of Pyoverdine production. Phytopathology 84:139-146.

24. McSpadden Gardener, B. B. 2007. Diversity and ecology of biocontrol Pseudomonas spp. in agricultural systems. Phytopathology 97:221-226.

25. McSpadden Gardener, B. B., Gutierrez, L. J., Joshi, R., Edema, R., and Lutton, E. 2005. Distribution and biocontrol potential of phlD+ pseudomonads in corn and soybean fields. Phytopathology 95:715-724.

26. McSpadden Gardener, B. B., Schroeder, K. L., Kalloger, S. E., Raaijmakers, J. M., Thomashow, L. S., and Weller, D. M. 2000. Genotypic and phenotypic diversity of phlD-containing Pseudomonas strains isolated from the rhizosphere of wheat. Appl. Environ. Microbiol. 66:1939-1946.

27. Mengel, D. B., and Barber, S. A. 1974. Rate of nutrient uptake per unit of corn root under field conditions. Agronomy 66:399-402.

28. Minyo, R. J., Jr., Geyer, A. B., Thomison, P. R., Bishop, B. L., and Lohnes, D. G. 2007 Ohio Crop Performance Test. Available from http://www.oardc.ohio-state.edu/corntrials/ via internet accessed 10 January 2008.

29. Naseby, D. C., and Lynch, J. M. 1999. Effects of Pseudomonas fluorescens $\mathrm{F} 113$ on ecological functions in the pea Rhizosphere are dependent on pH. Microb. Ecol. 37:248-256.

30. Raaijmakers, J. M., and Weller, D. M. 1998. Natural plant protection by 2,4-diacetylphloroglucinol-producing Pseudomonas spp. in take-all decline soils. Mol. Plant-Microbe Interact. 11:144-152.

31. Raaijmakers, J. M., and Weller, D. M. 2001. Exploiting genotypic diversity of 2,4-diacetylphloroglucinol-producing Pseudomonas spp.: Characterization of superior root-colonizing P. fluorescens strain Q8r1-96. Appl. Environ. Microbiol. 67:2545-2554.

32. Rezzonico, F., Zala, M., Keel, C., Duffy, B., Moënne-Loccoz, Y., and Défago, G. 2007. Is the ability of biocontrol fluorescent pseudomonads to produce the antifungal metabolite 2,4-diacetylphloroglucinol really synonymous with higher plant protection? New Phytol. 173:861-872.

33. Rotenberg, D., Joshi, R., Benitez, M.-S., Gutierrez Chapin, L., Camp, A., Zumpetta, C., Osborne, A., Dick, W. A., and McSpadden Gardener, B. B. 
2007. Farm management effects on rhizosphere colonization by native populations of 2,4-diacetylphloroglucinol-producing Pseudomonas spp. and their contributions to crop health. Phytopathology 97:756-766.

34. Schenk, M. K., and Barber, S. A. 1979. Phosphate uptake by corn as affected by soil characteristics and root morphology. Soil Sci. Soc. Am. J. 43:880-883.

35. Schmidt, C. S., Agostini, F., Leifert, C., Killham, K., and Mullins, C. E. 2004. Influence of soil temperature and matric potential on sugar beet seedling colonization and suppression of Pythium damping-off by the antagonistic bacteria Pseudomonas fluorescens and Bacillus subtilis. Phytopathology 94:351-363.

36. Sheskin, D. J. 1997. Handbook of Parametric and Nonparametric Statistical Procedures. CRC Press, Boca Raton, FL.

37. Summer, M. E., and Noble, A. D. 2003. Soil acidification: The world story. Pages 1-27 in: Handbook of Soil Acidity. Z. Rengel, ed. Marcel Dekker, New York .

38. Taiz, L., and Zeiger, E., eds. 2006. Plant Physiology, 4th ed. Sinauer Associates.

39. Vincent, M. N., Harrison, L. A., Brackin, J. M., Kovacevich, P. A., Mukerji, P., Weller, D. M., and Pierson, E. A. 1991. Genetic analysis of the antifungal activity of soilborne Pseudomonas aureofaciens strain. Appl. Environ. Microbiol. 57:2928-2934.

40. Wang, Y., Ohara, Y., Nakayashiki, H., Tosa, Y., and Mayama, S. 2005 Microarray analysis of the gene expression profile induced by the endophytic plant growth-promoting rhizobacteria Pseudomonas fluorescens FPT9601-T5 in Arabidopsis. Mol. Plant-Microbe Interact. 18:385-396.

41. Warncke, D., and Brown, J. R. 1998. Potassium and other basic cations. Pages 31-33 in: Recommended Chemical Soil Test Procedures for the North Central Region. NCR Publ. No. 221. Missouri Agricultural Experiment Station, Columbia.

42. Watson, M. E., and Brown, J. R. 1998. pH and lime requirement Pages 13-16 in: Recommended Chemical Soil Test Procedures for the North Central Region. NCR Publ. No. 221. Missouri Agricultural Experiment Station, Columbia.

43. Weller, D. M., Raajmakers, J. M., McSpadden Gardener, B. B., and Thomashow, L. S. 2002. Microbial populations responsible for specific soil suppressiveness to plant pathogens. Annu. Rev. Plant Pathol. 40:309348.

44. White, D. G., ed. 1999. Compendium of Corn Disease. 3rd ed. American Phytopathological Society, St. Paul, MN. 